University of Nebraska - Lincoln

DigitalCommons@University of Nebraska - Lincoln

\title{
Isolation of the phycodnavirus PBCV-1 by biological laser printing
}

Lisa A. Fitzgerald

U.S. Naval Research Laboratory, Washington, DC, lisa.fitzgerald@nrl.navy.mil

Peter K. Wu

U.S. Naval Research Laboratory, Washington, DC

James Gurnon

University of Nebraska-Lincoln, jgurnon2@unl.edu

Justin C. Biffinger

U.S. Naval Research Laboratory, Washington, DC

Bradley R. Ringeisen

U.S. Naval Research Laboratory, Washington, DC

See next page for additional authors

Follow this and additional works at: https://digitalcommons.unl.edu/plantpathpapers

Part of the Plant Pathology Commons

Fitzgerald, Lisa A.; Wu, Peter K.; Gurnon, James; Biffinger, Justin C.; Ringeisen, Bradley R.; and Van Etten, James L., "Isolation of the phycodnavirus PBCV-1 by biological laser printing" (2010). Papers in Plant Pathology. 201.

https://digitalcommons.unl.edu/plantpathpapers/201

This Article is brought to you for free and open access by the Plant Pathology Department at DigitalCommons@University of Nebraska - Lincoln. It has been accepted for inclusion in Papers in Plant Pathology by an authorized administrator of DigitalCommons@University of Nebraska - Lincoln. 


\section{Authors}

Lisa A. Fitzgerald, Peter K. Wu, James Gurnon, Justin C. Biffinger, Bradley R. Ringeisen, and James L. Van Etten 


\title{
Isolation of the phycodnavirus PBCV-1 by biological laser printing
}

\author{
Bradley R. Ringeisen ${ }^{\mathrm{a}}$, James L. Van Etten ${ }^{\mathrm{b}, \mathrm{c}}$ \\ a Chemistry Division, U.S. Naval Research Laboratory, Washington, DC 20375, USA \\ ${ }^{\mathrm{b}}$ Department of Plant Pathology, University of Nebraska, Lincoln, NE 68583, USA \\ ${ }^{\mathrm{c}}$ Nebraska Center for Virology, University of Nebraska, Lincoln, NE 68583, USA
}

Lisa A. Fitzgerald ${ }^{\mathrm{a}, *}$, Peter K. Wu ${ }^{\mathrm{a}, 1}$, James R. Gurnon ${ }^{\mathrm{b}}$, Justin C. Biffinger ${ }^{\mathrm{a}}$,

\section{Article history:}

Received 22 December 2009

Received in revised form 31 March 2010

Accepted 8 April 2010

Available online $\mathrm{xxx}$

\section{Keywords:}

Chlorella virus PBCV-1

Phycodnaviridae

Chlorella NC64A

Biological laser printing (BioLP)

\section{A B S T R A C T}

The Phycodnaviridae family of viruses is diverse genetically but similar morphologically. These viruses infect eukaryotic algal hosts from both fresh and marine waters, and are an important component of aqueous environments. They play important roles in the dynamics of algal blooms, nutrient cycling, algal community structure, and possibly gene transfer between organisms. As such, it is important to identify new viruses within the Phycodnaviridae family. Biological laser printing (BioLP) was used to isolate single virus particles from solution. BioLP prints droplets containing a single virus particle directly onto a host medium, thereby enabling viruses to be isolated from unmodified samples. This manuscript demonstrates how BioLP can be used as a single-step method to separate and possibly identify viruses from complex environmental specimens.

Published by Elsevier B.V.
Members and prospective members of the family Phycodnaviridae constitute a diverse genetically, but similar morphologically, group of viruses with eukaryotic algal hosts from both fresh and marine waters (Dunigan et al., 2006). The family derives its name from two distinguishing characteristics: (i) "phyco," from their algal hosts, and (ii) "dna," because all of these viruses have dsDNA genomes (160-560 kb) (Wilson et al., 2005). The phycodnaviruses are among the virioplankton recently recognized as important ecological elements in aqueous environments (Chen et al., 1996). More than $50 \%$ of the carbon dioxide fixed on the planet is by phytoplankton (Behrenfeld et al., 2006), including cyanobacteria and eukaryotic microalgae. Therefore, phycodnaviruses play a significant ecological role in the life cycle of their algal hosts.

Accumulating genetic evidence indicates that phycodnaviruses, along with poxviruses, iridoviruses, African swine fever virus (ASFV), and the recently discovered Mimivirus (Raoult et al., 2004), have a common evolutionary ancestor, perhaps arising at the point of eukaryogenesis approximately 2.0-2.7 billion years ago (Brocks et al., 1999; Feng et al., 1997; Glansdorff, 2000; Han and Runnegar, 1992). All of these viruses share 9 gene products, and 33 additional

\footnotetext{
* Corresponding author at: Chemistry Division, U.S. Naval Research Laboratory, 4555 Overlook Avenue, SW, Code 6113, Washington, DC 20375, USA. Tel.: +1 202 404 2553; fax: +1 2024048119.

E-mail address: lisa.fitzgerald@nrl.navy.mil (L.A. Fitzgerald).

1 Current address: Department of Physics and Engineering, Southern Oregon University, Ashland, OR 97520, USA.
}

gene products are present in at least 2 of these 5 viral families (Iyer et al., 2001, 2006; Raoult et al., 2004). Collectively, these viruses along with the other asfariviruses and coccolithoviruses are referred to as Nucleo-Cytoplasmic Large DNA Viruses (NCLDVs) (Iyer et al., 2001).

New aquatic viruses, including the phycodnaviruses, are continually being discovered as more environmental samples are examined. Ongoing metagenomic studies indicate a greater viral diversity than could have been imagined just a few years ago (Hambly and Suttle, 2005; Wommack and Colwell, 2000). The ease with which new viruses are found suggests that aquatic viruses may represent the greatest source of uncharacterized genetic diversity on Earth (Hambly and Suttle, 2005). Appreciation for this diversity is limited, in part, because algal viruses have only been identified for about $0.1 \%$ of the $\sim 40,000$ known eukaryotic algal species (Guiry and Rindi, 2005). Oddly, it is possible that both biological and genetic diversity are the unifying themes of the phycodnaviruses.

Phycodnaviruses are large icosahedrons (mean diameter of $160 \pm 60 \mathrm{~nm}$ ) and, where known, have an internal membrane that is required for infection. Phylogenetic analyses of the $\delta$-DNA polymerases from the phycodnaviruses indicate that they are more closely related to each other than to other dsDNA viruses, and that they form a monophyletic group, consistent with a common ancestor (Wilson et al., 2005). The viruses fall into six clades, which correlate with their hosts, and each has been given genus status. Often the genera can be distinguished by additional properties, including lytic versus lysogenic life styles, or linear versus circular genomes (Wilson et al., 2005). Members of the genus Chlorovirus (chlorella viruses) infect fresh water algae, whereas members of the 
other five genera (Coccolithovirus, Phaeovirus, Prasinovirus, Prymnesiovirus, and Raphidovirus) infect marine algae.

The chlorella viruses are relatively new to virologists but are the best-studied phycodnaviridae system since their initial discovery in 1981 (Van Etten et al., 1981). However, their discovery is contributing scientific and economic benefits despite our limited knowledge. For example, chlorella viruses are sources of new and unexpected genes (Fitzgerald et al., 2007a,b,c). These genes not only encode commercially important enzymes such as DNA restriction endonucleases, but many viral-encoded enzymes are the smallest member of their class. Consequently, these proteins often serve as ideal biochemical models for mechanistic and structural studies. For this reason and others, a new method was developed by which to isolate individual viral particles from aquatic samples that form plaques on algal host cell lawns. Paramecium bursaria chlorella virus 1 (PBCV-1) was used for these studies as it is the prototype chlorella virus.

For these experiments, the viral host Chlorella sp. NC64A was grown on MBBM medium as described previously (Van Etten et al., 1983; Van Etten et al., 1981). The cells were sub-cultured into fresh MBBM at a low density and grown to a concentration of $1.0-2.0 \times 10^{7}$ cells $/ \mathrm{mL}$. The cells were then concentrated to $4.0 \times 10^{8}$ cells $/ \mathrm{mL}$ by centrifugation for $5 \mathrm{~min}$ at $5000 \mathrm{rpm}$ using a Sorvall rotor at $4{ }^{\circ} \mathrm{C}$, and the pellet was suspended in fresh MBBM. The concentrated Chlorella NC64A suspension $(300 \mu \mathrm{L})$ was added to a $30 \mathrm{~mm} \times 100 \mathrm{~mm}$ tube containing $5 \mathrm{~mL}$ of MBBM soft agar ( $0.75 \%$ MBBM agar) and mixed briefly by rolling the tube between the palms of the hands. The contents were poured onto a solidified $25 \mathrm{~mL}$ MBBM agar (1.5\% agar) plate.

Cell printing is defined as the ability to drop-and-place living cells onto a surface with micron-scale precision (Ringeisen et al., 2006). There are several types of cell printers described in the literature ranging from jet-based to extrusion-based techniques (Ringeisen et al., 2006). In general, jet-based techniques are more precise than extrusion-based methods, and typically deposit lowvolume droplets $(0.5-1000 \mathrm{pL})$ in rapid succession $(100-10,000 / \mathrm{s})$ (Barron et al., 2005a; Ringeisen et al., 2002; Roth et al., 2004; Xu et al., 2006). Due to the low volume of each printed droplet, biological laser printing, or BioLP, is able to pattern single cells onto different surfaces with micron-scale resolution (Barron et al., 2005b; Othon et al., 2008; Xu et al., 2004). In addition, previous studies have determined that cells deposited by BioLP are unharmed as well (Barron et al., 2004b; Chen et al., 2006; Hopp et al., 2005; Ringeisen et al., 2001, 2004).

In this work, BioLP was used to isolate single virus particles from a concentrated solution. The BioLP apparatus, configured to print living cells from liquid culture, was described previously (Barron et al., 2004a,b) and a detailed description of how it was used for virus printing is described below. The concentrated virus suspen$\operatorname{sion}(2 \mu \mathrm{L})$ was spread evenly onto a $1-\mathrm{cm}^{2}$ quartz slide coated with

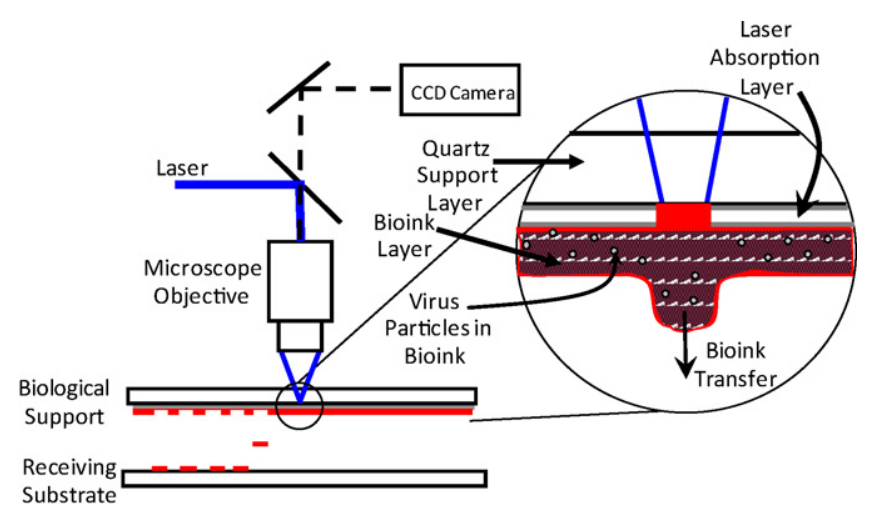

Fig. 1. Biological laser printing (BioLP) schematic. The support is comprised of three layers: a transparent support, an energy conversion layer (gray) and the liquid cell culture (red). (For interpretation of the references to color in this figure legend, the reader is referred to the web version of the article.)

a layer of $85-\mathrm{nm}$ thick titanium dioxide. This slide was inverted and placed into the BioLP apparatus as shown in Fig. 1. A quadrupled UV Nd:YAG laser pulse $(266 \mathrm{~nm}, 2 \mathrm{~ns})$ was directed through a microscope objective and focused at the quartz/titanium dioxide interface of the biological support. This biological support is comprised of three layers: a transparent quartz slide, a thin laser absorption coating (an $85 \mathrm{~nm}$ thick $\mathrm{TiO}_{2}$ layer), and a thicker biological fluid layer ("bioink" spread to $\sim 10 \mu \mathrm{m}$ thick). The light energy from the laser pulse was converted into heat energy at the quartz $/ \mathrm{TiO}_{2}$ layer, and the heat vaporized a portion of the virus culture medium (bioink) in direct contact with the metal oxide layer (Barron et al., 2004b). High speed images of this energy transfer process have show that a liquid jet is forced away from the quartz slide (Barron et al., 2005a). The quartz slide and receiving substrate were computer controlled and could be moved independently, such that with successive laser pulses, patterns could be directly written drop-by-drop onto the receiving substrate. For this study, a 300 spot array ( $\sim 50 \mu \mathrm{m}$ diameter droplets spaced $5 \mathrm{~mm}$ apart so that single plaques could form without merging with neighbors) was formed onto agar plates positioned directly below the quartz slide. The slide/agar plate distance was held at $0.5 \mathrm{~mm}$ throughout the duration of printing. The quadrupled UV Nd:YAG laser pulse used in this study has a laser frequency of $10 \mathrm{~Hz}$, thus depositing 10 droplets per second onto the agar plates. However, it should be noted that a high-throughput laser printing device equipped with an IR pulsed laser has been shown to fire between 1 and $100 \mathrm{kHz}$ equating to a possibility of printing 100,000 droplets per second (Guillemot et al., 2009).

Arrays of virus particles were printed onto the Chlorella NC64A lawn and were allowed to grow in continuous light at $25^{\circ} \mathrm{C}$. At low virus particle concentrations $\left(10^{8} \mathrm{pfu} / \mathrm{mL}\right)$, most printed spots

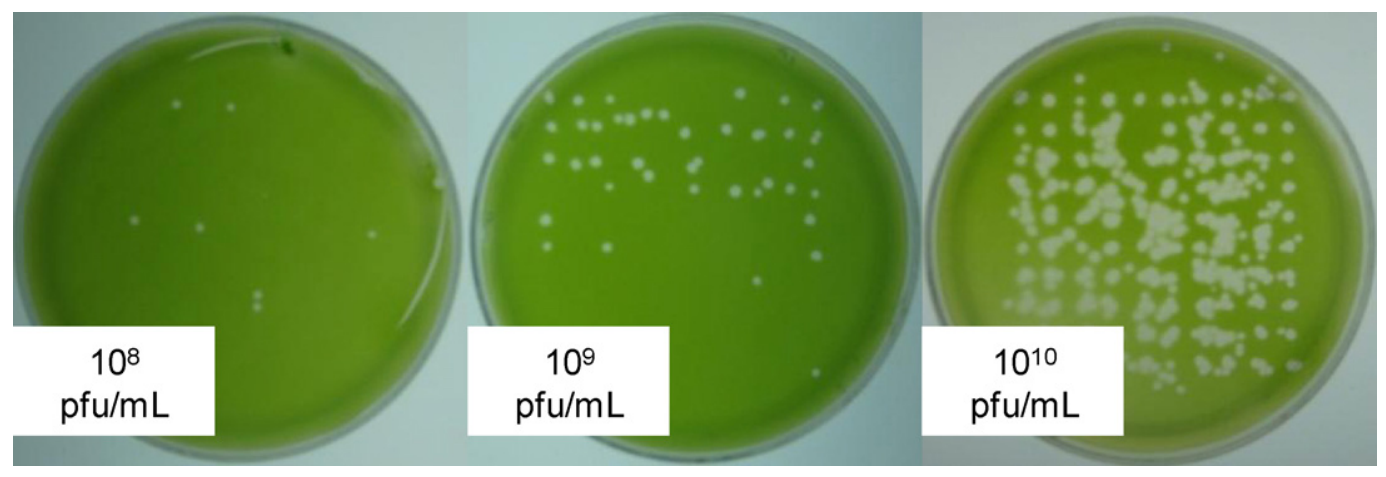

Fig. 2. Biological laser printing (BioLP) of chlorella virus PBCV-1 onto its host lawn of Chlorella NC64A. 
contained either one or zero plaque-forming virus particles as evidenced by the presence or absence of a circular plaque, respectively (Fig. 2). Higher concentrations of virus particles $\left(10^{10} \mathrm{pfu} / \mathrm{mL}\right)$ yielded arrays with multiple plaques (i.e. multiple virus particles) printed per spot.

This is the first report showing the ability to print chlorella virus particles onto a host and opens the possibility to use this technique for other virus systems. There are several applications that could arise from such a technique. For example, one could identify new viruses belonging to the Phycodnaviridae family by printing environmental water samples onto different algal hosts to quickly isolate single virus particles. Established analytical methods that compare DNA polymerase (Clasen and Suttle, 2009) or major capsid sequence fragments (Larsen et al., 2008) could then be used to specifically identify the virus. As with bacterial printing, this method could lead to industrial or medical applications, where viruses could be printed for use as biological sensors, or human samples could be printed for rapid identification of infectious agents. In addition to the mentioned applications, this technique allows for the possibility of isolating new virus particles which would not be identified by using a standard plaque assay. With the advancement of high-throughput laser printing technology, one can print $\sim 100,000$ droplets per second (Guillemot et al., 2009). Therefore, with the ability to print multiple drops, one would be able to isolate low-titer virus particles. Furthermore, with the use of a 3456-well microtiter plate, one could quickly isolate over 3000 virus particles within milliseconds. This technique not only allows for rapid screening of environmental samples for the discovery of new virus particles but saves on reagent costs and sample scarcity.

\section{Acknowledgments}

This investigation was supported in part by the Office of Naval Research through Naval Research Laboratory 6.2 funds PE\#62236N (BRR), Public Health Service Grant GM32441 (JLVE) and NIH grant P20RR15635 from the COBRE program of the National Center for Research Resources (JLVE). LAF was supported by a National Research Council research associateship.

\section{References}

Barron, J., Young, H., Dlott, D., Darfler, M., Krizman, D., Ringeisen, B., 2005a. Printing of protein microarrays via a capillary-free fluid jetting mechanism. Proteomics $5,4138-4144$.

Barron, J.A., Krizman, D.B., Ringeisen, B.R., 2005b. Laser printing of single cells: statistical analysis, cell viability, and stress. Ann. Biomed. Eng. 33, 121130.

Barron, J.A., Rosen, R., Jones-Meehan, J., Spargo, B.J., Belkin, S., Ringeisen, B.R., 2004a. Biological laser printing of genetically modified Escherichia coli for biosensor applications. Biosens. Bioelectron. 20, 246-252.

Barron, J.A., Wu, P., Ladouceur, H.D., Ringeisen, B.R., 2004b. Biological laser printing: a novel technique for creating heterogeneous 3-dimensional cell patterns. Biomed. Microdevices 6, 139-147.

Behrenfeld, M.J., O'Malley, R.T., Siegel, D.A., McClain, C.R., Sarmiento, J.L., Feldman, G.C., Milligan, A.J., Falkowski, P.G., Letelier, R.M., Boss, E.S., 2006. Climate-driven trends in contemporary ocean productivity. Nature 444, 752-755.

Brocks, J.J., Logan, G.A., Buick, R., Summons, R.E., 1999. Archean molecular fossils and the early rise of eukaryotes. Science $285,1033-1036$.

Chen, C.Y., Barron, J.A., Ringeisen, B.R., 2006. Cell patterning without chemical surface modification: cell-cell interacftions between bovine aortic endothelial cells (BAEC) on a homogeneous cell-adherent hydrogel. Appl. Surf. Sci. 252, 8641-8645.

Chen, F., Suttle, C.A., Short, S.M., 1996. Genetic diversity in marine algal virus communities as revealed by sequence analysis of DNA polymerase genes. Appl. Environ. Microbiol. 62, 2869-2874.
Clasen, J.L., Suttle, C.A., 2009. Identification of freshwater phycodnaviridae and their potential phytoplankton hosts, using DNA pol sequence fragments and a genetic-distance analysis. Appl. Environ. Microbiol. 75, 991-997.

Dunigan, D.D., Fitzgerald, L.A., Van Etten, J.L., 2006. Phycodnaviruses: a peek at genetic diversity. Virus Res. 117, 119-132.

Feng, D.F., Cho, G., Doolittle, R.F., 1997. Determining divergence times with a protein clock: update and reevaluation. Proc. Natl. Acad. Sci. U.S.A. 94, 13028-13033.

Fitzgerald, L.A., Graves, M.V., Li, X., Feldblyum, T., Hartigan, J., Van Etten, J.L., 2007 a. Sequence and annotation of the 314-kb MT325 and the 321-kb FR483 viruses that infect Chlorella Pbi. Virology 358, 459-471.

Fitzgerald, L.A., Graves, M.V., Li, X., Feldblyum, T., Nierman, W.C., Van Etten, J.L., 2007b. Sequence and annotation of the 369-kb NY-2A and the 345-kb AR158 viruses that infect Chlorella NC64A. Virology 358, 472-484.

Fitzgerald, L.A., Graves, M.V., Li, X., Hartigan, J., Pfitzner, A.J., Hoffart, E., Van Etten, J.L., 2007c. Sequence and annotation of the 288-kb ATCV-1 virus that infects an endosymbiotic chlorella strain of the heliozoon Acanthocystis turfacea. Virology $362,350-361$

Glansdorff, N., 2000. About the last common ancestor, the universal life-tree and lateral gene transfer: a reappraisal. Mol. Microbiol. 38, 177-185.

Guillemot, F., Souquet, A., Catros, S., Guillotin, B., Lopez, J., Faucon, M., Pippenger, B., Bareille, R., Remy, M., Bellance, S., Chabassier, P., Fricain, J.C., Amedee, J., 2009. High-throughput laser printing of cells and biomaterials for tissue engineering. Acta Biomater. (Epub ahead of print).

Guiry, M.D., Rindi, F., 2005. AlgaeBase Version 3.0. National University of Ireland, Galway.

Hambly, E., Suttle, C.A., 2005. The viriosphere, diversity, and genetic exchange within phage communities. Curr. Opin. Microbiol. 8, 444-450.

Han, T.M., Runnegar, B., 1992. Megascopic eukaryotic algae from the 2.1-billionyear-old Negaunee iron-formation, Michigan. Science 257, 232-235.

Hopp, B., Smausz, T., Kresz, N., Barna, N., Bor, Z., Kolozsvari, L., Chrisey, D., Szabo, A., Nogradi, A., 2005. Survival and proliferative ability of various living cell types after laser-induced forward transfer. Tissue Eng. 11, 1817-1823.

Iyer, L.A., Balaji, S., Koonin, E.V., Aravind, L., 2006. Evolutionary genomics of nucleocytoplasmic large DNA viruses. Virus Res. 117, 156-184.

Iyer, L.M., Aravind, L., Koonin, E.V., 2001. Common origin of four diverse families of large eukaryotic DNA viruses. J. Virol. 75, 11720-11734.

Larsen, J.B., Larsen, A., Bratbak, G., Sandaa, R.A., 2008. Phylogenetic analysis of members of the Phycodnaviridae virus family, using amplified fragments of the major capsid protein gene. Appl. Environ. Microbiol. 74, 3048-3057.

Othon, C.M., Wu, X., Anders, J.J., Ringeisen, B.R., 2008. Single-cell printing to form three-dimensional lines of olfactory ensheathing cells. Biomed. Mater. 3, 034101

Raoult, D., Audic, S., Robert, C., Abergel, C., Renesto, P., Ogata, H., La Scola, B., Suzan, M., Claverie, J.M., 2004. The 1.2-megabase genome sequence of mimivirus. Science 306, 1344-1350.

Ringeisen, B., Othon, C., Barron, J., Young, D., Spargo, B., 2006. Jet-based methods to print living cells. Biotechnol. J. 1, 930-948.

Ringeisen, B., Wu, P., Kim, H., Pique, A., Auyeung, R., Young, H., Chrisey, D., Krizman, D., 2002. Picoliter-scale protein microarrays by laser direct write. Biotechnol. Prog. 18, 1126-1129.

Ringeisen, B.R., Chrisey, D.B., Pique, A., Young, H.D., Modi, R., Bucaro, M., JonesMeehan, J., Spargo, B.J., 2001. Generation of mesoscopic patterns of viable Escherichia coli by ambient laser transfer. Biomaterials 23, 161-166.

Ringeisen, B.R., Kim, H., Barron, J.A., Krizman, D.B., Chrisey, D.B., Jackman, S., Auyeung, R.Y.C., Spargo, B.J., 2004. Laser printing of pluripotent embryonal carcinoma cells. Tissue Eng. 10, 483-491.

Roth, E.A., Xu, T., Das, M., Gregory, C., Hickman, J.J., Boland, T., 2004. Ink-jet printing for high-throughput cell patterning. Biomaterials 25, 3707-3715.

Van Etten, J.L., Burbank, D.E., Xia, Y., Meints, R.H., 1983. Growth cycle of a virus, PBCV-1, that infects Chlorella-like algae. Virology 126, 117-125.

Van Etten, J.L., Meints, R.H., Burbank, D.E., Kuczmarski, D., Cuppels, D.A., Lane, L.C., 1981. Isolation and characterization of a virus from the intracellular green alga symbiotic with Hydra viridis. Virology 113, 704-711.

Wilson, W.H., Van Etten, J.L., Schroeder, D.S., Nagasaki, K., Brussaard, C., Delaroque, N., Bratbak, G., Suttle, C., 2005. Phycodnaviridae. In: Fauquet, C.M., Mayo, M.A., Maniloff, J., Desselverger, U., Ball, L.A. (Eds.), Virus Taxonomy: Classification and Nomenclature of Viruses, Vol. Eighth Report of the International Committee of the Taxonomy of Viruses. Elsevier Academic Press, San Diego, pp. $163-175$.

Wommack, K.E., Colwell, R.R., 2000. Virioplankton: viruses in aquatic ecosystems. Microbiol. Mol. Biol. Rev. 64, 69-114.

Xu, T., Gregory, C.A., Molnar, P., Cui, X., Jalota, S., Bhaduri, S.B., Boland, T., 2006. Viability and electrophysiology of neural cell structures generated by the inkjet printing method. Biomaterials 27, 3580-3588.

Xu, T., Petridou, S., Lee, E.H., Roth, E.A., Vyavahare, N.R., Hickman, J.J., Boland, T., 2004 . Construction of high-density bacterial colony arrays and patterns by the ink-jet method. Biotechnol. Bioeng. 85, 29-33. 